\title{
PENGARUH EARNING PER SHARE, PRICE TO BOOK VALUE, CASH FLOW OPERATING, STOCK RETURN, DIVIDEND PAYOUT RATIOTERHADAP PENILAIAN EKUITAS PERUSAHAAN
}

\author{
Sharen Santoso Rafli dan Yanti \\ Fakultas Ekonomi Universitas Tarumanagara Jakarta \\ Email: Yanti@fe.untar.ac.id
}

\begin{abstract}
The purposeof this studyis to analyze the effect of Earnings Per Share, Price to Book Value, Cash Flow Operating, Stock Return, Dividend Payout Ratio to theEquity Valuation oncompanies listedinthe Indonesia Stock Exchange. A total sample of 47 manufacturing company was selected through purposive sampling method. The results of this study is the earnings per share, dividend payout ratio, and operating cash flow do not have significant influence on equity valuation. Conversely, the price-to-book value and stock return have significant influence on equity valuation. Suggestions for future research is to expand the period of research and use others independent variables that have not been tested in this study for example: sales, interest rates, retained earnings, stock price, and net income.
\end{abstract}

Keywords: Earnings Per Share, Price to Book Value, Cash Flow Operating, Stock Return, Dividend Payout Ratio, Equity.

\begin{abstract}
Abstrak: Tujuan penelitian ini adalah untuk meneliti pengaruh Earnings Per Share, Price to Book Value, Cash Flow Operating, Stock Return, Dividend Payout Ratio terhadap penilaian ekuitas pada perusahaan publik yang terdaftar di Bursa Efek Indonesia. Sebanyak 47 perusahaan manufaktur terpilih sebagai unit observasi melalui metode purposive sampling.Berdasarkan hasil penelitian ditemukan bahwa earning per share,dividend payout ratio, dan cash flow operating tidak mempunyai pengaruh terhadap penilaian ekuitas. Sebaliknya Price to book value, Stock return mempuyai pengaruh yang signifikan terhadap penilaian ekuitas. Saran bagi penelitian selanjutnya adalah memperluas tahun penelitian agar hasil penelitian lebih mencerminkan kondisi penilaian ekuitas yang lebih baik dan penambahan variable bebaslain yang belum diuji misalnya: sales, interest rates, retained earning, stock price, dan net income.
\end{abstract}

Kata Kunci: Earnings Per Share, Price to Book Value, Cash Flow Operating, Stock Return, Dividend Payout Ratio, Equity.

\section{PENDAHULUAN}

Perekonomian di era globalisasi yang semakin kompetitif menghadapkan perusahaan-perusahaan pada suatu lingkungan bisnis yang kompleks dan dinamis. Lingkungan bisnis seperti ini akan terus mengalami perubahan secara cepat dan pesat seiring dengan kemajuan zaman. Perusahaan membutuhkan strategi yang efisien untuk menghadapi persaingan. Salah satu cara perusahaan memperkenalkan keberadaan perusahaan tersebut kepada masyarakat yaitu dengan cara melakukan go public.Hal tersebut merupakan salah satu mekanisme untuk mengembangkan modal dengan maksud untuk meningkatkan keuangan perusahaan-perusahaan go public. 
Tujuan suatu perusahaan dalam jangka panjang adalah mengoptimalkan nilai perusahaan.Pada saat perusahaan mengalami kerugian atau sedang menghadapi kesulitan keuangan maka terjadi perubahan relevansi nilai terhadap data informasi keuangan.Konsep kesatuan usaha memisahkan antara manajemen dan pemilik, informasi tentang ekuitas pemegang saham menjadi sangat penting karena hal tersebut menunjukkan hubungan antara perusahaan (perseroan) dengan pemegang saham.

Kerangka dasar Standar Akuntansi Indonesia (2002), Ikatan Akuntan Indonesia (IAI) mendefinisikan ekuitas sebagai berikut (pasal 49) yaitu: "Ekuitas adalah hak residual atas aktiva perusahaan setelah dikurangi semua kewajiban”.Pada umumnya, tujuan pelaporan informasi ekuitas pemegang saham adalah menyediakan informasi kepada yang berkepentingan tentang efisiensi dan kepengurusan (stewardship)manajemen.

Investor perlu menilai ekuitas mereka yang ada pada perusahaan melalui laporan keuangan yang disampaikan perusahaan.Menurut Ohslon (2005) laporan keuangan memberi fungsi dalam melaporkan perubahan kepemilikan ekuitas perusahaan.Laporan ini termasuk unsur-unsur dasar neraca dan laporan laba rugi yang masing-masing diwakili oleh nilai buku ekuitas dan laba.Unsur nilai buku ekuitas (equity book value) dan laba per saham (earning per share) memiliki pengaruh terhadap pembentukan harga saham.

Menurut sudut pandang pemegang saham, ekuitas yang mereka investasikan pada sebuah perusahaan merupakan hak atau kekayaan yang tertanam pada perusahaan tersebut. Maka dari itu penilaian ekuitas bagi para pemegang saham sangatlah penting untung mengetahui seberapa besar return yang akan peroleh nantinya dari modal yang mereka tanamkan.

Berdasarkan sudut pandang kesatuan usaha, ekuitas merupakan hutang yang perusahaan kepada pemegang saham.Karena itu, penilian ekuitas dapat juga digambarkan sebagai hubungan yuridis antara perusahaan dan pemegang saham.Hal ini membuat penilaian ekuitas penting yaitu karena dapat melaporkan atau menyajikan informasi atau elemen agar pemegang saham mengetahui ekuitas yang mereka miliki di dalam perusahaaan tersebut dan agar hubungan yuridis tetap dapat dipertahankan.

Pentingnya pengungkapan informasi penilaian ekuitas perusahaanakan sangat dipengaruhi oleh tujuan penyajian informasi tersebut kepada pemakai laporan keuangan. Pada umumnya, tujuan pelaporan informasi penilaian ekuitas perusahaan adalah menyelidiki akan informasi kepada yang berkepentingan tentang efisiensi dan kepengurusan (stewardship) manajemen serta menyediakan informasi tentang riwayat serta prospek investasi pemilik dan pemegang ekuitas lainnya.

Penilaian terhadap ekuitas di suatu perusahaan dapat dilakukan dengan berbagai cara. Secara spesifik, penilaian ekuitas dapat dilakukan dengan perhitungankeuangan.Perhitungan keuangan ini digunakan untuk menghubungkan perkiraan-perkiraan yang terdapat dalam laporan keuangan. Dalam penilitian ini, ada beberapa rumus keuangan yang digunakan, yaitu earning per share, price to book value, cash flow operating, stock return, dan dividend payout ratio.

Berdasarkan penelitian terdahulu, terdapat hasil pro dan kontra terhadap penilaian ekuitas perusahaan. Pada umumnya penilaian ekuitas perusahaan dapat dinilai dengan earning per share, price to book value, cash flow operating, stock return, dan dividend payout ratiodimana unsur-unsur tersebut mempunyai kaitan terhadap penilaian ekuitas (Al Hares et al., 2011;Gupta, 2007; Alfaraih dan Alanezi, 2011;Ohlson, 2005). Namun beberapa penelitian lain menyatakan bahwa earning per share, price to book value, cash 
flow operating, stock return, dan dividend payout ratiotidak memiliki dampak terhadap penilaian ekuitas, dimana pengujiannya menyatakan tidak adanya hasil yang signifikan(Kwon, 2009;Davis dan Gordon, 2005;Nissim dan Penham, 2003; Pope dan Wang, 2005).

\section{KAJIAN TEORI}

Signalling Theory. Menurut Suwardjono (2011:584) teori pesignalan (signaling theory) melandasi pengungkapan sukarela.Manajemen selalu berusaha untuk mengungkapkan informasi private yang menurut pertimbangannya sangat diminati oleh investor dan pemegang saham khususnya kalau informasi tersebut merupakan berita baik (good news).Manajemen juga berminat menyampaikan informasi yang dapat meningkatkan kredibilitasnya dan kesuksesan perusahaan meskipun informasi tersebut tidak diwajibkan.Beberapa penelitian akademik juga menunjukkan bahwa makin besar perusahaan makin banyak pengungkapan sukarela yang disampaikan.

Wolk (1997:91) menyatakan bahwa : "There is information astmmetry between the firm and outsiders because insiders (the firm) know more about a company and its future prospects than outsiders (investors)."

Ekuitas.Kieso, Weygandt, Warfield (2011:772) menyatakan bahwa : "equityis the residual interest in the assets of the company after deducting all liabilities."Menurut Suwardjono (2011:184):"Ekuitas atau asset bersih adalah hak residual terhadap asset suatu entitas yang masih tersisa setelah mengurangi asset dan kewajibannya dalam suatu badan usaha, ekuitas adalah hak pemelikan. Dalam organisasi nonbisnis, yang tidak terdapat hak pemilikan yang bermakna sama dengan pemilikan dalam badan usaha, asset bersih dibagi ke dalam tiga golongan atas dasar ada tidaknya pembatasan tetapan donor (donor-imposed restrictions)-asset bersih terbatas permanen, terbatas sementara, dan tak terbatas.”

Ohlson (2005) menyatakan bahwa terdapat 3 asumsi langsung dalam melakukan penilaian terhadap ekuitas yaitu: (1)Sebagai standar dalam model neoklasik dari penilaian sekuritas, nilai sekarang dari dividen yang diharapkan menentukan nilai pasar. Kerangka probabilistik mengindikasikan sebuah keadaan “anggapan obyektif”. Untuk menjaga halhal sederhana, netralitas risiko berlaku sehingga faktor diskon sama dengan tingkat bebas risiko; (2)Kepemilikan tetap dari ekuitas akuntansi menerapkan: hubungan penerapan surplus bersih, dan dividen mengurangi nilai buku saat ini tetapi tidak mempengaruhi laba rugi tahun berjalan; (3)Kerangka model linier dari time-series/deret waktu perilaku abnormal dari pendapatan. Sebagaimana yang telah ditulis, variabel ini didefinisikan sebagai laba rugi tahun berjalan dikurangi nilai waktu dari nilai buku awal periode yang bebas resiko, yaitu, pendapatan dikurangi biaya untuk penggunaan modal.

Penelitian inimenggunakan market to book ratio yang mencerminkan nilai pasar relativeterhadap nilai ekuitas perusahaan.Market to Book Ratio adalah rasio dari nilai pasar perlembar saham biasa atas nilai buku perlembar ekuitas. Nilai buku per lembar mencerminkan nilai ekuitas pemilik yang tercatat pada neraca perusahaan dan mencerminkan klaim pemilik yang tersisa atas suatu aktiva.Sedangkan nilai pasar per lembar saham mencerminkan kinerja perusahaan di masyarakat umum dimana nilai pasar pada suatu saat dipengaruhi oleh pilihan dan tingkah laku dari mereka yang terlibat dipasar. 
Penilaian ekuitas dalam penilitian ini juga didasarkan pada beberapa teori yang mendukungnya seperti signaling theory, discounted dividned theory dan free cash flow theory. Penelitian yang dilakukan oleh Rayhon dan Jansen (2014) menyatakan bahwa discounted dividend theory dapat diterapkan dalam penialian ekuitas.Signalling theory juga merupakan dasar yang digunakan untuk memberikan report (signal) kepada investor kapan waktu yang tepat untuk menanamkan investasinya pada suatu perusahaan.

Tujuan dari penyajian penilaian ekuitas ini yaitu pentingnya pengungkapan informasi penilaian ekuitas perusahaan akan sangat dipengaruhi oleh tujuan penyajian informasi tersebut kepada pemakai laporan keuangan. Pada umumnya, tujuan pelaporan informasi penilaian ekuitas perusahaan adalah menyelidiki akan informasi kepada yang berkepentingan tentang efisiensi dan kepengurusan (stewardship) manajemen sertamenyediakan informasi tentang riwayat serta prospek investasi pemilik dan pemegang ekuitas lainnya.

Earning Per Share. Investormempunyai berbagai tujuan dalam menanamkan modalnya di pasar modal yaitu salah satunya tujuannya adalah untuk memperoleh keuntungan atas investasi sahamnya berupa kenaikan harga saham atau dividen.Sesuai dengan tujuan dasar suatu perusahaan yaitu memaksimalkan keuntungan maka setiap kebijakan yang berhubungan dengan memaksimalkan harga saham selalu berkaitan erat dengan kemampuan perusahaan untuk meningkatkan kemakmuran baik untuk meningkatkan nilai perusahaan maupun untuk memaksimalkan kemakmuran pemegang sahamnya.

Menurut Brighman dan Houston (2001:367) Pertumbuhan dividen terjadi disebabkan akibat dari pertumbuhan laba per saham.Sedangkan pertumbuhan laba sendiri disebabkan oleh sejumlah faktor termasuk (1) inflasi, (2) jumlah laba yang ditahan dan diinvestasikan kembali oleh perusahaan, dan (3) tingkat pengembalian yang diperoleh perusahaan atas ekuitasnya.Menurut Brighman dan Houston (2001:28) meskipun arus kas sangat menentukan nilai pemegang saham, namun manajer keuangan tidak dapat mengabaikan pengaruh keputusan manajerial terhadap earning per share yang dilaporkan, karena pengumuman laba akan disampaikan kepada investor.

Price To Book Value.Secara umum, price to book value adalah sebuah indikatorpenting dalam investasi walaupun sebagian analis menganggap sudah kurang relevan lagi karena berbagai alasan. Semakin rendah nilai price to book valuesuatu saham maka saham tersebut dikategorikan undervalued, yang mana sangat baik untuk memutuskan investasi jangka panjang. Nilai rendah price to book value ini harus disebabkan oleh turunnya harga saham, sehingga harga saham berada di bawah nilai bukunya atau nilai sebenarnya.

Nilai buku (book value) per lembar saham menunjukkan aktiva bersih (net asset) yang dimiliki oleh pemegang saham dengan memiliki satu lembar saham. Karena aktiva bersih adalah sama dengan total ekuitas pemegang saham, maka nilai buku per lembar saham adalah total ekuitas dibagi dengan jumlah saham yang beredar. (Jogiyanto, 2003:82).

Cash Flow Operating.Laporan arus kas (statement of cash flows) adalah laporan keuangan yang memberikan informasi mengenai arus kas masuk dan arus kas keluar dalam suatu periode waktu tertentu di perusahaan.Laporan arus kas diklasifikasikan menjadi 3 aktivitas, yaitu (1) aktivitas operasi (operating activity), (2) aktivitas investasi (investing activity), dan (3) aktivitas pendanaan (financing activity).Menurut Kieso, Weygandt, Warfield 
(2011:1242):"The primary purpose of statement of cash flow is to provide information about a company's cash receipts and cash payment during a period. Asecondary objective is to provide cash basis information about the company's operating, investing, and financing activities."

Menurut PSAK No. 2 (2009: 2.5), “Arus kas adalah arus masuk dan arus keluar kas atau setara kas.” Laporan arus kas mempunyai beberapa manfaat dalam memeberikan informasi mengenai keadaan suatu perusahaan.Menurut pernyataan PSAK No. 2 tahun (2009: 2.3), laporan arus kas memiliki manfaat yaitu :"Jika digunakan dalam kaitannya dengan laporan keuangan lainnya, maka laporan arus kas dapat memberikan informasi yang memungkinkan pengguna untuk mengevaluasi perubahan dalam aset neto netitas, struktur keuangan (termasuk likuiditas dan solvabilitias) dan kemampuannya mempengaruhi jumlah serta waktu arus kas dalam rangka penyesuaian terhadap keadaan dan peluang yang berubah, Informasi arus kas berguna untuk menilai dan membandingkan niali arus kas masa depan dari berbagai entitas. Informasi tersebut juga meningkatkan daya banding pelaporan kinerja operasi berbagai entitas karena dapat meniadakan pengaruh penggunaan perlakuan akuntansi yang berbeda terhadap transaksi dan peristiwa yang sama.”

Stock Return.Motivasi para investor dalam melakukan investasi adalah harapan untuk memperoleh return yang sesuai. Tanpa adanya return, para investor tidak akan bersedia melakukan investasi adalah untuk memperoleh return yang baik secara langsung maupun tidak langsung.Ekspetasi dari para investor terhadap investasinya adalah apabila dana yang diinvestasikannya dapat mendatangkan keuntungan atau return yang tinggi dengan risiko tertentu. Sehingga dalam setiap pengambilan keputusan investasi dalam saham tertentu perlu mempertimbangkan secara teliti dan cermat, apakah saham yang diinvestasikan akan memberikan return yang memuaskan dengan beban risiko yang ditanggung.

Menurut Jogiyanto (2003:110):“Return merupakan selisih dari harga investasi sekarang relative dengan harga periode yang masa lalu. Jika harga investasi sekarang lebih tinggi dari harga investasi periode lalu ini berarti terjadi keuntungan modal (capital gain), sebaliknya terjadi kerugian modal (capital loss)."

Dividend Payout Ratio.Dividen payout ratio menggambarkan tingkat persentase dari laba yang dibagi menjadi dividen. Perusahaan yang efektif adalah bila dapat menghasilkan laba sama dalam penggunaan aset yang lebih sedikit.Menurut Darmadji dan Fakhruddin (2006:201) rasio pembayaran dividen (dividend payout ratio) merupakan rasio yang mengukur perbandingan dividen terhadap laba perusahaan. Dividend payout ratio yang berkurang dapat mencerminkan laba perusahaan yang makin berkurang. Akibatnya sinyal buruk akan muncul karena mengindikasikan bahwa perusahaan kekurangan dana. Kondisi ini akan menyebabkan preferensi investor akan suatu saham berkurang karena investor memiliki preferensi yang sangat kuat atas dividen.

Hipotesis.Earning per share merupakan salah satu alat yang dapat digunakan untuk menghitung analisis keuangan. Namun berdasarkan penilitian sebelumnya terdapat peniliti yang menyatakan bahwa earning per share berpengaruh signifikan terhadap penilaian ekuitas perusahaan (Alfariah dan Alanezi, 2011; Nissim dan Penhem, 2003; Pope dan Wang, 2005; Al Hares et al., 2011; Xu et al., 2007; Ohlson, 2005). Sementara dalam 
penelitian yang lain ditemukan bahwa earning per share berpengaruh tidak signifikan terhadap penilaian ekuitas hal ini diungkapkan oleh Kwon (2009). Oleh karena itu, hipotesis pertama dalam penelitian ini adalah:

H1 :Earning Per Share berpengaruh signifikan terhadap penilaian ekuitas.

Price to book value merupakan suatu rasio yang digunakan untuk menghitung aktiva bersih yang dimiliki oleh pemegang saham dengan satu lembar saham yang dimilikinya.Menurut Gupta (2007) dan Kwon (2009menyatakan bahwa hubungan antara price to book value terhadap penilaian ekuitas menghasilkan pengaruh yang siginifikan.Namun terdapat penilitian yang menyatakan bahwa price to book value tidak memiliki hubungan yang signifikan terhadap penilaian ekuitas suatu perusahaan (Davis dan Gordon, 2005). Oleh karena itu, hipotesis kedua dalam penelitian ini adalah:

H2 :Price To Book Value berpengaruh signifikan terhadap penilaian ekuitas.

Arus kas di sebuah perusahaan menunujukkan apakah operasional dan kinerja sebuah perusahaan berjalan dengan baik atau tidak.Hasil tersebut dapat mempengaruhi penilaian ekuitas sebuah perusahaan. Terdapat penilitian yang menyatakan bahwa cash flowoperating memiliki pengaruh yang signifikan terhadap penilian ekuitas ustau perusahaan (Kwon, 2009); (Davis and Gordon, 2005). Terdapat hasil penilitian yang menyatakan bahwa cash flow operating tidak secara siginifikan berpengaruh terhadap penilaian ekuitas suatu perusahaan (Al Hares et al., 2011). Oleh karena itu, hipotesis ketiga dalam penelitian ini adalah:

H3 :Cash Flow Operating berpengaruh signifikan terhadap penilaian ekuitas.

Ketika seorang investor menginvestasikan sahamnya di sebuah perusahaan, secara otomatis seorang investor ingin mengetahui seberapa besar return yang akan didapatkan berdasarkan investasi yang ditanamkannya. Return yang dimiliki oleh seorang investor menentukan apakah investor mengalami kerugian atau keuntungan. Bedasarkan penilitian yang telah ada terdapat hasil penilitian yang menyatakan bahwa stock return berpengaruh secara signifikan terhadap penilaian ekuitas (Alfaraih dan Alanezi, 2011). Terdapat hasil penelitian yang menyatakan bahwa stock return tidak memiliki pengaruh yang signifikan terhadap penilaian ekuitas (Nissim dan Penham, 2003). Oleh karena itu, hipotesis keempat dalam penelitian ini adalah:

H4 :Stock Return berpengaruh signifikan terhadap penilaian ekuitas.

Dividen payout ratio dapat digunakan sebagai salah satu faktor untuk menghitung penilaian ekuitas suatu perusahaan dengan mengetahui dividen lembar per sham dan juga mengetahui laba per saham. Menurut Ohlson (2005) menyatakan bahwa divided payout ratio memiliki hubungan yang signifikan terhadap penilaian ekuitas. Terdapat hasil penilitian yang menyatakan bahwa dividend payout ratio tidak secara signifikan berpengaruh terhadap penilaian ekuitas (Popped dan Wang, 2005). Oleh karena itu, hipotesis kelima dalam penelitian ini adalah:

H5 :Dividend Payout Ratio berpengaruh signifikan tergadap penilaian ekuitas.

\section{METODE}

Populasi dan Metode Pengambilan Sampel.Populasi yang digunakan dalam penelitian ini adalah seluruh perusahaan manufaktur yang terdaftar di Bursa Efek Indonesia selama periode penelitian yaitu dari tahun 2011-2013. Sampel penelitian ini adalah perusahaan manufaktur di Bursa Efek Indonesia, yang dipilih dengan menggunakan purposive 
sampling method dengan kriteria sebagai berikut : (1) Perusahaan manufaktur yang terdaftar di Bursa Efek Indonesia dalam kurun waktu 2011-2013, (2) Perusahaan yang tidak mengalami kerugian selama tahun 2011-2013, (3) Perusahaan yang membagikan dividen tunai selama periode 2011-2013, (4) Laporan keuangan perusahaan dinyatakan dalam mata uang Rupiah, dan (5) Perusahaan yang harga sahamnya terdaftar sejak tahun 2010-2013.

Berdasarkan kriteria yang ada maka diperoleh jumlah sampel penelitian selama tahun 2011-2013 adalah sebanyak 47 perusahaan manufaktur. Jumlah data selama 3 tahun yang valid digunakan dalam penelitian ini adalah berjumlah 112 setelah dilakukan uji outlier.

Operasional Variabel. Variabel dependen dalam penilitian ini adalah penilaian ekuitas. Penilaian ekuitas perusahaan akan sangat dipengaruhi oleh tujuan penyajian informasi tersebut kepada pemakai laporan keuangan. Pada umumnya, tujuan pelaporan informasi penilaian ekuitas perusahaan adalah menyelidiki akan informasi kepada yang berkepentingan tentang efisiensi dan kepengurusan (stewardship) manajemen serta menyediakan informasi tentang riwayat serta prospek investasi pemilik dan pemegang ekuitas lainnya. Penelitian ini menggunakan proksi market to book ratio untuk penilaian ekuitas karena sangat dipengaruhi oleh pemilihan metode akuntansi yang digunakan perusahaan. Berdasarkan penilitian ini penilaian ekuitas dihitung dengan menggunakan proksi market to book value dengan rumus (Brigham dan Houston, 2001:92):

$$
\text { Market to Book Value }=\frac{\text { Harga pasar per saham }}{\text { Nilai buku per saham }}
$$

Adapun variable independen atau variable bebas yang digunakan adalah earning per share, price to book value, cash flow operating, stock return, dan dividend payout ratio.

1. Earning Per Share. Investor mempunyai berbagai tujuan dalam menanamkan modalnya di pasar modal yaitu salah satunya tujuannya adalah untuk memperoleh keuntungan atas investasi sahamnya berupa kenaikan harga saham atau dividen.Sesuai dengan tujuan dasar suatu perusahaan yaitu memaksimalkan keuntungan maka setiap kebijakan yang berhubungan dengan memaksimalkan harga saham selalu berkaitan erat dengan kemampuan perusahaan untuk meningkatkan kemakmuran baik untuk meningkatkan nilai perusahaan maupun untuk memaksimalkan kemakmuran pemegang sahamnya.

Perhitungan earning per share (Brighman dan Houston, 2001:28)adalah :

$$
\text { Earning Per Share }=\frac{\text { Net Income }}{\text { Outstanding share }}
$$

2. Price to Book Value. Price to book value adalah perbandingan antara harga pasar dan nilai buku saham.Semakin besar rasio price to book value semakin tinggi perusahaan dinilai oleh para pemodal relatif dibandingkan dengan dana yang telah ditanamkan di perusahaan.

Rumus untuk menghitung price to book valueadalahShare Price Per Sharedibagi dengan Book Value Per Share. Sedangkanrumus nilai buku per lembar saham adalah adalah ekuitas saham biasa dibagi dengan jumlah saham yang beredar(Brigham dan Houston, 2001:92). 
3. Cash Flow Operating. Laporan arus kas (statement of cash flows) adalah laporan keuangan yang memberikan informasi mengenai arus kas masuk dan arus kas keluardalam suatu periode waktu tertentu di perusahaan.Laporan arus kas diklasifikasikan menjadi 3 aktivitas, yaitu (1) aktivitas operasi (operating activity), (2) aktivitas investasi (investing activity), dan (3) aktivitas pendanaan (financing activity). Penelitian ini akan membahas cash flow operating.

Persamaan rumus yang digunakan untuk cash flow operating berdasarkan jurnal Davis dan Gordon (2005) yaitu dengan menggunakan cash flow operating yang berasal dari aktivitas operasi (Kieso, Weygandt dan Warfield, 2008:1244) :

\begin{tabular}{|l|r|r|}
\hline Cash flows from operating activities & \\
\hline Net Income & $\mathrm{xxx}$ \\
\hline $\begin{array}{l}\text { Adjustments to reconcile net income to net cash provided } \\
\text { (used) by operating activities } \\
\text { *List of individual items }\end{array}$ & $\mathrm{xxx}$ & $\mathrm{xxx}$ \\
\hline Net cash provided (used) by operating activities & & $\mathrm{xxx}$ \\
\hline
\end{tabular}

4. Stock Return. Ekspetasi dari para investor terhadap investasinya adalah apabila dana yang diinvestasikannya dapat mendatangkan keuntungan atau return yang tinggi dengan risiko tertentu. Sehingga dalam setiap pengambilan keputusan investasi dalam saham tertentu perlu mempertimbangkan secara teliti dan cermat, apakah saham yang diinvestasikan akan memberikan return yang memuaskan dengan beban risiko yang ditanggung.

Persamaan rumus untuk menghitung stock return adalah (Jogiyanto, 2003:111)

$$
\text { Stock Return }=\frac{\mathrm{P}_{\mathrm{it}}-\mathrm{P}_{\mathrm{it}-1}+\mathrm{d}_{\mathrm{it}}}{\mathrm{P}_{\mathrm{t}-1}}
$$

5. Dividend Payout Ratio. Dividen payout ratio menggambarkan tingkat persentase dari laba yang dibagi menjadi dividen. Perusahaan yang efektif adalah bila dapat menghasilkan laba sama dalam penggunaan asset yang lebih sedikit.Persamaan rumus untuk menghitung dividend payout ratio adalah (Darmadji dan Fakhruddin, 2006:201):

$$
\text { Dividend Payout Ratio }=\quad \frac{\text { Dividend per share }}{\text { Earning per share }}
$$

Perhitungan rumus earning per share (Brighman dan Houston, 2001:28) :

$$
\text { Earning Per Share }=\frac{\text { Net Income }}{\text { Outstanding share }}
$$

Uji Hipotesis. Model regresi berganda digunakan untuk mengetahui bagaimana pengaruh earning per share, price to book value, cash flow operating, stock return dan dividend payout ratio terhadap penilaian ekuitas yang dihasilkan oleh perusahan manufaktur yang terdaftar di Bursa Efek Indonesia. Untuk menguji pengaruh variabel dependen dengan masing-masing variabel independen digunakan model empiris pada persamaan berikut: 


$$
\mathrm{Y}^{\prime}=\mathrm{a}+\beta_{1} \mathrm{EPS}+\beta_{2} \mathrm{PBV}+\beta_{3} \mathrm{CFO}+\beta_{4} \mathrm{SR}+\beta_{5} \mathrm{DPR}+\varepsilon
$$

Dimana $Y^{\prime}=$ penilaian ekuitas; $a=$ konstanta; besarnya sama dengan $y=0, x=0 ; \beta_{1}$, $\beta_{2}, \ldots, \beta_{5}=$ koefisien regresi; EPS= earning per share; $\mathrm{PBV}=$ price to book value; $\mathrm{CFO}=$ cash flow operating; $\mathrm{SR}=$ stock return; $\mathrm{DPR}=$ dividend payout ratio; $\varepsilon=$ error.

Model regresi yang baik harus memenuhi kriteria BLUE (Blue Linear Unbiased Estimator). Oleh karena itu uji asumsi klasik dilakukan, yaitu meliputi: Uji Normalitas, Uji Multikolinearitas, Uji Heteroskedastisitas, dan Uji Autokorelasi.Selanjutnya Uji F dilakukan untuk mengetahui goodness of fit dari suatu model regresi yang digunakan dengan tingkat signifikansi 5\% (Ghozali, 2012: 98).

Untuk menunjukkan besarnya hubungan antara dua atau lebih variabel independen terhadap variabel dependen secara serentak dilakukan uji koefisien korelasi ganda (uji R). Nilai koefisien korelasi ganda (R) berkisar antara 0 sampai 1 . Nilai R yang semakin mendekati 1 menunjukkan hubungan variabel yang semakin erat. Jika nilai $\mathrm{R}$ mendekati 0 maka menunjukkan hubungan variabel yang semakin lemah (Priyatno, 2010: 65).

Di samping itu, untuk mengetahui kemampuan suatu model dalam menerangkan variasi variabel dependen dilakukan Uji Koefisien Determinasi (Uji Adjusted $\mathrm{R}$ Square).Nilai koefisien determinasi adalah nol dan satu. Nilai koefisien determinasi yang kecil berarti kemampuan variabel independen dalam menjelaskan variasi variabel dependen sangat terbatas. Nilai yang mendekati satu berarti variabel independen memberikan hampir semua informasi yang dibutuhkan untuk menerangkan variasi variabel dependen(Ghozali, 2012: 97).

Uji-t dilakukan untuk menguji signifikan secara parsial pengaruh variabel independen terhadap variabel dependen dalam model regresi yang sudah dihasilkan.Dalam penelitian ini digunakan tingkat signifikan 5\% (Ghozali, 2011: 98).

\section{HASIL DAN PEMBAHASAN}

Statistik Deskriptif. Berdasarkan hasil penyeleksian sampel, didapatkan 47 perusahaan manufaktur yang kemudian dijadikan sampel dalam penelitian ini. Data yang digunakan dalam penelitian ini diperoleh dari laporan keuangan dan juga data yang secara lengkap yang dipublikasikan dalam www.idx.co.id dan http://finance.yahoo.com. Semua informasi yang berkaitan dengan variabel yang diteliti dalam penelitian ini diambil dari laporan keuangan perusahaan yang telah diaudit selama tahun 2011-2013.

Data tersebut diolah dengan menggunakan analisis regresi berganda. Perhitungan statistik dalam analisis regresi linear berganda yang digunakan dalam penelitian ini adalah dengan menggunakan bantuan program komputer SPSS for Windows versi 21. Berikut ini disajikan tabel yang memperlihatkan statistik deskriptif dari variabel-variabel yang diteliti dan telah memenuhi uji asumsi klasik.

Uji Asumsi Klasik. Pengujian yang pertama adalah uji normalitas.Penelitian ini menggunakan uji One-Sample Kolmogorov-Smirnov (K-S) untuk mendeteksi apakah suatu model regresi berdistribusi normal atau tidak. Uji One-Sample Kolmogorov-Smirnov melihat nilai asymptotic significance yang dihasilkan oleh variabel terikat dan unstandardized residual, dimana nilainya harus lebih dari tingkat signifikansi $\alpha>0,05$ untuk bisa dinyatakan bahwa model regresi berdistribusi normal. Untuk mencapai data 
yang dapat berdistribusi secara normal, maka penelitian ini menggunakan data uji outlier dimana batas buang data yaitu kurang dari -3 atau lebih dari +3 .

Tabel 1. Statistik Deskriptif

\begin{tabular}{lrrrrr}
\hline & $\mathrm{N}$ & \multicolumn{1}{c}{ Minimum } & \multicolumn{1}{c}{ Maximum } & \multicolumn{1}{c}{ Mean } & \multicolumn{1}{c}{ Std. Deviation } \\
\hline EPS & 112 & 1,2400 & 7832,3600 & 686,103214 & 1291,9753792 \\
PBV & 112 &, 3100 & 8,1200 & 2,039554 & 1,6684715 \\
CFO & 112 & $-6,08 E 15$ & $9,33 E 12$ & $9,69 E 11$ & $1,97 \mathrm{E} 12$ \\
SR & 112 &,- 8300 & 1,1900 &, 198929 &, 3679805 \\
DPR & 112 &, 0000 & 7,0800 &, 446250 &, 8216366 \\
PE & 112 &, 2800 & 8,2700 & 2,112589 & 1,8268186 \\
Valid N & 112 & & & & \\
(listwise) & & & & & \\
\hline
\end{tabular}

Sumber: Hasil Pengolahan SPSS

Hasil uji One-Sample Kolmogorov-Smirnov dapat dilihat pada tabel di bawah ini:

Tabel 2. Hasil Uji Normalitas

One-Sample Kolmogorov-Smirnov Test

\begin{tabular}{|ll|r|}
\hline & & Unstandardized Residual \\
\hline N & Mean & 112 \\
& Std. Deviation &, 0000000 \\
& Absolute & 0,29428831 \\
Most Extreme Differences & Positive & 0,119 \\
& Negative & 0,119 \\
Kolmogorov-Smirnov Z & &,- 081 \\
Asymp. Sig. (2-tailed) & & 1,264 \\
\hline
\end{tabular}

Sumber: Hasil Pengolahan SPSS

Berdasarkan Tabel 2 dari hasil uji One-Sample Kolmogorov-Smirnov dapat dilihat nilai asymptotic significance sebesar 0,082, yaitu lebih besar dari tingkat signifikansi $\alpha>0,05$. Hal ini menunjukkan bahwa model regresi berdistribusi normal dan layak digunakan untuk penelitian.

Pengujian asumsi klasik yang keduaadalah uji autokorelasi. Uji autokorelasi dilakukan dengan uji Langrange Multiplier(LM test). Uji autokolerasi dengan LM test terutama digunakan untuk sample besar diatas 100 observasi. Uji LM akan menghasilkan statistik Breusch-Godfrey.Pengujian Breusch-Godfrey (BG test) dilakukan dengan melakukan regresi variabel penggangu (residual). Pengujian ini digunakan pada tingkat signifikansi 5\% ( $\alpha=0,05)$,apabila salah satu variabel lebih kecil dari 0,05 maka dapat terjadi gejala autokolerasi. 
Tabel 3. Hasil Uji Autokorelasi (Breusch-Godfrey)

\begin{tabular}{|c|c|c|c|c|c|c|}
\hline \multirow[t]{2}{*}{ Mode } & & \multicolumn{2}{|c|}{$\begin{array}{l}\text { Unstandardized } \\
\text { Coefficients }\end{array}$} & \multirow{2}{*}{$\begin{array}{c}\begin{array}{c}\text { Standardized } \\
\text { Coefficients }\end{array} \\
\text { Beta }\end{array}$} & \multirow[t]{2}{*}{$\mathrm{t}$} & \multirow[t]{2}{*}{ Sig. } \\
\hline & & B & Std. Error & & & \\
\hline \multirow{6}{*}{1} & (Constant) &,- 015 & ,046 & &,- 325 & ,746 \\
\hline & EPS & $-2,695 \mathrm{E}-005$ & ,000 &,- 118 & $-1,178$ & ,241 \\
\hline & $\mathrm{P} / \mathrm{BV}$ &,- 002 & ,019 &,- 011 &,- 106 & 916 \\
\hline & CFO & $-1,141 \mathrm{E}-013$ & ,000 &,- 094 &,- 899 & 371 \\
\hline & SR & 122 & ,077 & 153 & 1,581 & 117 \\
\hline & DPR & 057 & ,036 & 160 & 1,604 & 112 \\
\hline
\end{tabular}

Sumber: Hasil Pengolahan Data SPSS

Uji autokolerasi menunjukkan bahwa tidak terjadi gejala autokolerasi, kesimpulan ini dilihat dari nilai signifikan yang dihasilkan dari earning per share, price to book value, cash flow operating, stock return, dividend payout ratio diatas 0,05 dimana nilai signifikansi untuk earning per share sebesar 0,241, price to book value sebesar 0,916, cash flow operating sebesar 0,371, nilai stock return sebesar 0,117, dan dividend payout ratio sebesar 0,112 .

Pengujian yang ketiga adalah uji multikolonieritas. Penelitian ini melihat nilai Tolerance dan Variance Inflation Factor untuk mendeteksi ada atau tidaknya multikolonieritas di dalam model regresi. Nilai Variance Inflation Factor yang lebih dari 10 dan nilai Tolerance kurang dari 0,10 menunjukkan bahwa variabel tersebut mengalami gejala multikolonieritas dengan variabel bebas lainnya sedangkan nilai Variance Inflation Factor yang kurang dari 10 dan nilai Tolerance lebih dari 0,10 menunjukkan bahwa variabel tersebut tidak mengalami gejala multikolonieritas dengan variabel bebas lainnya. Hasil uji multikolonieritas dapat dilihat pada Tabel di bawah ini:

Tabel 4. Hasil Uji Multikolonieritas

\begin{tabular}{|c|c|c|c|}
\hline \multicolumn{4}{|c|}{ Coefficients ${ }^{a}$} \\
\hline \multirow{2}{*}{\multicolumn{2}{|c|}{ Model }} & \multicolumn{2}{|c|}{ Collinearity Statistics } \\
\hline & & Tolerance & VIF \\
\hline \multirow{6}{*}{1} & (Constant) & & \\
\hline & EPS & ,883 & 1,133 \\
\hline & PBV & ,754 & 1,325 \\
\hline & CFO & ,815 & 1,226 \\
\hline & SR & 956 & 1,046 \\
\hline & DPR & 896 & 1,116 \\
\hline
\end{tabular}

Berdasarkan Tabel 4 hasil uji multikolonieritas dapat dilihat nilai Toleranceearning per share sebesar 0,883. Nilai Toleranceprice to book value sebesar 0,754. Nilai Tolerancecash flow operating sebesar 0,815. Nilai Tolerancestock return 0,956. Nilai Tolerancedividen payout ratio sebesar 0,896. Nilai Tolerance untuk earning per share, price to book value, cash flow operating, stock return, dan dividen payout ratio lebih besar dari 0,10. Berdasarkan nilai Tolerance yang diperoleh maka dapat disimpulkan bahwa model regresi tidak terdapat multikolonieritas. 
Nilai Variance Inflation Factorearning per share sebesar 1,133. Nilai Variance Inflation Factorprice to book value sebesar 1,325. Nilai Variance Inflation Factorcash flow operating sebesar 1,226. Nilai Variance Inflation Factorstock return 1,046. Nilai Variance Inflation Factordividen payout ratio sebesar 1,116. Nilai Variance Inflation Factoruntuk earning per share, price to book value, cash flow operating, stock return, dan dividen payout ratio kurang dari 10. Berdasarkan nilai Variance Inflation Factor yang diperoleh maka dapat disimpulkan bahwa model regresi tidak terdapat multikolonieritas dan layak digunakan untuk penelitian.

Pengujian asumsi yang keempat adalahUji heteroskedastisitas. Penelitian ini menggunakan uji Koefisien Korelasi Peringkat Spearman untuk mendeteksi apakah suatu model regresi terdapat heteroskedastisitas atau tidak.Nilai significance yang lebih dari tingkat signifikansi $\alpha>0,05$ menunjukkan bahwa model regresi tersebut tidak terdapat heteroskedastisitas sedangkan nilai significance yang kurang dari tingkat signifikansi $\alpha<0,05$ menunjukkan bahwa model regresi tersebut mengalami heteroskedastisitas. Hasil uji Koefisien Korelasi Peringkat Spearman dapat dilihat pada tabel di bawah ini:

Tabel 5. Hasil Uji Koefisien Korelasi Peringkat Spearman

\begin{tabular}{|c|c|c|c|c|c|c|c|c|}
\hline & & & EPS & PBV & $\mathrm{CFO}$ & SR & DPR & $\begin{array}{c}\text { Unstandardized } \\
\text { Residual }\end{array}$ \\
\hline & & $\begin{array}{l}\text { Correlation } \\
\text { Coefficient }\end{array}$ & 1,000 &, $378^{* *}$ &, $354^{* *}$ & , 142 & ,075 &,- 012 \\
\hline & EPS & Sig. (2-tailed) & & ,000 & ,000 & 134 & 430 & 902, \\
\hline & & $\mathrm{N}$ & 112 & 112 & 112 & 112 & 112 & 112 \\
\hline & & $\begin{array}{l}\text { Correlation } \\
\text { Coefficient }\end{array}$ &, $378^{* *}$ & 1,000 &, $574^{* *}$ &, $264^{* *}$ &, $449^{* *}$ &,- 047 \\
\hline & PBV & Sig. (2-tailed) &, 000 & . & ,000 & ,005 & ,000 & 619 \\
\hline & & $\mathrm{N}$ & 112 & 112 & 112 & 112 & 112 & 112 \\
\hline & & $\begin{array}{l}\text { Correlation } \\
\text { Coefficient }\end{array}$ &, $354^{* *}$ &, $574^{* *}$ & 1,000 & ,080 &, $343^{* *}$ &,- 014 \\
\hline & CFO & Sig. (2-tailed) &, 000 & ,000 & . & ,404 & ,000 & ,885 \\
\hline Spearman's & & $\mathrm{N}$ & 112 & 112 & 112 & 112 & 112 & 112 \\
\hline rho & & $\begin{array}{l}\text { Correlation } \\
\text { Coefficient }\end{array}$ & ,142 &, $264^{* *}$ & ,080 & 1,000 & ,072 &,- 073 \\
\hline & SR & Sig. (2-tailed) & 134 & ,005 & ,404 & . & ,449 & ,445 \\
\hline & & $\mathrm{N}$ & 112 & 112 & 112 & 112 & 112 & 112 \\
\hline & RPR & $\begin{array}{l}\text { Correlation } \\
\text { Coefficient }\end{array}$ & ,075 &, $449^{* *}$ &, $343^{* *}$ & ,072 & 1,000 &,- 086 \\
\hline & DPK & Sig. (2-tailed) & ,430 & ,000 & ,000 & ,449 & $\cdot$ & ,369 \\
\hline & & $\mathrm{N}$ & 112 & 112 & 112 & 112 & 112 & 112 \\
\hline & & Correlation &,- 012 &,- 047 &,- 014 &,- 073 &,- 086 & 1,000 \\
\hline & Unsta & Coefficient & & & & & & \\
\hline & zed $R$ & Sig. (2-tailed) & 902 & ,619 & ,885 & , 445 & ,369 & . \\
\hline & & $\mathrm{N}$ & 112 & 112 & 112 & 112 & 112 & 112 \\
\hline
\end{tabular}

Sumber: Hasil Pengolahan SPSS

Berdasarkan tabel 5dapat dilihat nilai significance untuk earning per share sebesar 0,902. Nilai significance untuk price to book value sebesar 0,619. Nilai significance untuk cash flow operating sebesar 0,885. Nilai significance untuk stock return sebesar 0,445. Nilai significanceuntuk dividen payout ratio sebesar 0,369. Nilai significanceuntuk earning per share, price to book value, cash flow operating, stock return, dan dividen 
payout ratiolebih besar dari tingkat signifikansi $\alpha>0,05$. Berdasarkan nilai significance yang diperoleh maka dapat disimpulkan bahwa model regresi tidak terdapat heteroskedastisitas dan layak digunakan untuk penelitian

Uji Koefisien Korelasi Ganda (uji R).Hasil uji koefisien korelasi ganda (uji R) dapat dilihat pada tabel di bawah ini:

Tabel 6. Hasil Uji Koefisien Korelasi Ganda

\begin{tabular}{|c|c|c|c|c|}
\hline Model & $\mathrm{R}$ & $R$ Square & $\begin{array}{l}\text { Adjusted } R \\
\text { Square }\end{array}$ & $\begin{array}{l}\text { Std. Error of the } \\
\text { Estimate }\end{array}$ \\
\hline 1 & ,987 & ,974 & ,973 & ,3011491 \\
\hline
\end{tabular}

Berdasarkan Tabel 2 dapat dilihat bahwa nilai R yang diperoleh sebesar 0,987. Nilai 0,987 mendekati nilai 1 . Hal ini membuktikan bahwa hubungan antara earning per share, price to book value, cash flow operating, stock return, dan dividen payout ratioterhadappenilaian ekuitas berada dalam kategori kuat, karena memiliki nilai $\mathrm{R}$ yang hampir mendekati 1.

Uji Koefisien Determinasi (uji adjusted R square). Hasil uji koefisien determinasi dapat dilihat pada tabel di bawah ini:

Tabel 7. Hasil Uji Koefisien Determinasi

\begin{tabular}{lrrrr}
\hline Model & $\mathrm{R}$ & R Square & $\begin{array}{c}\text { Adjusted } R \\
\text { Square }\end{array}$ & $\begin{array}{c}\text { Std. Error of the } \\
\text { Estimate }\end{array}$ \\
\hline 1 &, $987^{\mathrm{a}}$ &, 974 &, 973 &, 3011491 \\
\hline
\end{tabular}

a. Predictors: (Constant), DPR, SR, EPS, CFO, PBV

b. Dependen Variable: PE

Sumber: Hasil Pengolahan SPSS

Berdasarkan Tabel 3 dari hasil uji koefisien determinasi dapat dilihat bahwa nilai adjusted $\mathrm{R}$ square yang diperoleh sebesar 0,974. Hasil perhitungan koefisien determinasi menunjukkan bahwa variabel independen dalam penelitian ini mampu menerangkan sebesar 97,4\% mengenai penilaian ekuitas pada perusahaan manufaktur yang terdaftar di Bursa Efek Indonesia. Sisanya yaitu sebesar 2,6\% dijelaskan oleh variabel lain yang tidak dimasukkan dalam penelitian ini.

Uji F.Hasil uji F dapat dilihat pada tabel di bawah ini: 
Tabel 8. Hasil Uji F

\begin{tabular}{|c|c|c|c|c|c|c|}
\hline Model & & $\begin{array}{l}\text { Sum of } \\
\text { Squares }\end{array}$ & $d f$ & Mean Square & $\mathrm{F}$ & Sig. \\
\hline \multirow{3}{*}{1} & Regression & 360,823 & 5 & 72,165 & 795,772 &, $000^{\mathrm{b}}$ \\
\hline & Residual & 9,613 & 106 & ,091 & & \\
\hline & Total & 370,437 & 111 & & & \\
\hline
\end{tabular}

a. Dependent Variable:PE

b. Predictors: (Constant),DPR, SR, EPS, CFO, PBV

Sumber: Hasil Pengolahan SPSS

Berdasarkan tabel 4 dari hasil uji F dapat dilihat bahwa nilai significance yang diperoleh sebesar 0,000 yaitu kurang dari tingkat signifikansi 5\% atau 0,05. Kesimpulan yang bisa diambil adalah Ho ditolak dan Ha diterima. Hal ini menunjukkan bahwamodel yang digunakan dalam penelitian ini adalah layak uji.

Uji t.Hasil uji t dapat dilihat pada tabel di bawah ini:

Tabel 9. Hasil Uji t

\begin{tabular}{|c|c|c|c|c|c|c|}
\hline \multirow{2}{*}{\multicolumn{2}{|c|}{ Model }} & \multicolumn{2}{|c|}{$\begin{array}{c}\text { Unstandardized } \\
\text { Coefficients }\end{array}$} & \multirow{2}{*}{$\begin{array}{c}\begin{array}{c}\text { Standardized } \\
\text { Coefficients }\end{array} \\
\text { Beta }\end{array}$} & \multirow[t]{2}{*}{$\mathrm{t}$} & \multirow[t]{2}{*}{ Sig. } \\
\hline & & B & Std. Error & & & \\
\hline \multirow{6}{*}{1} & (Constant) & ,148 & ,047 & & 3,125 & ,002 \\
\hline & EPS & $-2,359 \mathrm{E} 5$ & ,000 &,- 017 & $-1,002$ & 319 \\
\hline & PBV & 1,035 & 020 & 946 & 52,494 & , 000 \\
\hline & $\mathrm{CFO}$ & 1,218E13 & 000 & ,246 & 1,358 & 117 \\
\hline & SR & ,767 & ,079 & 154 & 9,654 & ,000 \\
\hline & DPR &,- 018 & 037 &,- 008 &,- 493 & 623 \\
\hline
\end{tabular}

a. Dependent Variable: PE

Sumber: Hasil Pengolahan SPSS

Berdasarkan Tabel 5 dari hasil uji t dapat disimpulkan bahwa persamaan regresi berganda adalah sebagai berikut:

$$
\mathrm{PE}=\text { 0,148-2,359E5EPS+1,035PBV+1,218E13CFO+0,767SR-0,018DPR }
$$

Keterangan: $\mathrm{PE}=$ Penilaian Ekuitas; EPS = Earning per share $; \mathrm{PBV}=$ Price to book value . $\mathrm{CFO}=$ Cash flow operating; $\mathrm{SR}=$ Stock return; $\mathrm{DPR}=$ Dividend payout ratio.

Hasil penelitian menunjukkan bahwa earning per sharemempunyai nilai significance sebesar 0,319 yang lebih besar dari tingkat signifikansi 0,05 sehingga dapat disimpulkan EPS tidak mempunyai pengaruh terhadap penilaian ekuitas. Earning per share menggambarkan mengenai pembagian antara net income dengan jumlah saham yang beredar.Semakin besar earning per share yang dimiliki sebuah perusahaan semakin baik citra perusahaan dimata para investor. Menurun Kwon (2009) meningkat atau menurunnya earning per share pada sebuah perusahaan tidak akan mempengaruhi nilai ekuitas, 
karenaearning per share sendiri lebih dipengaruhi dan mempengaruhi nilai arus kas operasi, dimana bila adanya peningkatan arus kas operasi maka nilai earning pada perusahaan tersebut juga akan ikut meningkat. Berdasarkan penjelasan di atas meningkatnya nilai earning per share tidak mempunyai pengaruh terhadap penilaian ekuitas.

Earning per share dan penilaian ekuitasmemiliki hubungan yang negatif disebabkan meningkatnya nilai earning per share dapat dipengaruhi oleh peningkatan laba atau juga penurunan outstanding share. Penurunan outstanding shareakan menyebabkan nilai book value meningkatyang pada akhirnya akan mempengaruhi penurunan nilai ekuitas. Berdasarkan hal tersebut menunjukkan peningkatan earning per shareakan membuat penilaian ekuitas menurun. Hasil penelitian ini konsisten dengan penelitian yang dilakukan oleh Kwon (2009) namun tidak konsisten dengan penelitian Alfariah dan Alanezi, 2011; Nissim dan Penhem, 2003; Pope dan Wang, 2005; Al Hares et al., 2011; $\mathrm{Xu}$ et al., 2007; Ohlson, 2005yang menyatakan bahwa earning per sharemempunyai pengaruh terhadap penilaian ekuitas.

Price to book valuevalue mempunyai nilai significance sebesar 0,000 yang lebih kecil dari tingkat signifikansi 0,05 sehingga dapat disimpulkan bahwa PBV mempunyai pengaruh yang signifikan terhadap penilaian ekuitas.Menurut Alfaraih (2011) Price to book value merupakan perhitungan untuk mengukur seberapa besar harga nilai harga saham daripada nilai buku per saham yang dimiliki sebuah perusahaan.Perusahaan yang baik akan memiliki nilai harga saham yang jauh lebih besar dibandingkan dengan nilai buku per saham dari perusahaan tersebut. Semakin besar nilai price to book value maka semakin tinggi pula nilai ekuitas dari perusahaan tersebut, yang mengakibatkan menarik minat para pemodal untuk menanamkan investasi pada perusahaan tersebut.Berdasarkan penjelasan di atas maka dapat disimpulkan bahwa price to book value mempunyai pengaruh terhadap penilaian ekuitas.

Price to book value dan penilaian ekuitas memiliki hubungan yang positif, yaitu nilai buku suatu perusahaan menjelaskan aktiva bersih yang dimiliki oleh pemegang saham dalam perusahaan, nilai aktiva bersih tersebut menjelaskan seberapa besar nilai ekuitas yang dimiliki perusahaan oleh karena itu apabila nilai price to book value meningkat maka penilaian ekuitas juga akan ikut meningkat. Hasil penelitian ini konsisten dengan penelitian yang dilakukan olehAlfaraih (2011), Gupta (2007), dan Kwon (2009) namun tidak konsisten dengan penelitian Davis dan Gordon (2005) yang menyatakan bahwa price to book value tidak mempunyai pengaruh terhadap penilaian ekuitas.

Cash flow operating mempunyai nilai significance sebesar 0,117 yang lebih besar dari tingkat signifikansi 0,05 sehingga dapat disimpulkan bahwa cash flow operatingtidak memiliki pengaruh terhadap penilaian ekuitas. Cash flow operating merupakan salah satu indikator untuk mengukur kemampuan dalam aktivitas operasi. Berdasarkan hal tersebut operasi arus kas hanya memberikan informasi mengenai sebuah perusahaan tentang kegiatan operasi yang dilakukannya dimana hal tersebut dapat mempengaruhi ekuitas dari sebuah perusahaan, maka apabila arus kas operasi sebuah perusahaan mengalami kerugianmaka nilai ekuitas juga akan berubah namun tidak akan memberikan dampak yang besar terhadap penilaian ekuitas di sebuah perusahaan. Hal ini menunjukkan bahwa cash flow operating tidak mempunyai pengaruh terhadap penilaian ekuitas, karena rugi atau tidaknya nilai operasi sebuah perusahaan tidak berdampak bagi nilai ekuitas dari perusahaan tersebut. 
Cash flow operating dan penilaian ekuitas memiliki hubungan yang positif, yaitu jika nilai cash flow operatingmeningkat maka penilaian ekuitasakan meningkat. Hasil penelitian ini konsisten dengan penelitian yang dilakukan oleh Al Hares et al. (2011) namun tidak konsisten dengan penelitian Kwon (2009) dan Davis and Gordon (2005) yang menyatakan bahwa cash flow operatingmempunyai pengaruh terhadap penilaian ekuitas.

Stock return mempunyai nilai significance sebesar 0,000 yang lebih kecil dari tingkat signifikansi 0,05 sehingga dapat disimpulkan bahwa stock return memiliki pengaruh terhadap penilaian ekuitas. Stock return merupakan suatu perhitungan yang memberikan informasi kepada pemegang saham seberapa besar pengembalian yang mereka terima atas penanaman saham yang telah dilakukannya. Perusahaan yang memiliki ekuitas yang baik secara otomatis memiliki harga pasar saham yang baik juga, dimana bila sebuah perusahaan memiliki ekuitas yang baik maka harga saham di perusahaan tersebut banyak dimintasi oleh investor untuk menanamkan sahamnya di situ. Berdasarkan hal tersebut bila harga saham sebuah perusahaan baik maka pengembalian yang dapat diberikan kepada penanam saham juga akan bernilai baik. Pengembalian saham yang semakin besar maka nilai ekuitas di perusahaan tersebut juga semakin baik. Berdasarkan penjelasan di atas maka dapat disimpulkan bahwa stock return mempunyai pengaruh terhadap penilaian ekuitas.

Stock return dan penilaian ekuitas memiliki hubungan yang positif, yaitu jika nilai stock returnmeningkat maka penilaian ekuitas juga ikut meningkat. Hasil penelitian ini konsisten dengan penelitian yang dilakukan oleh Alfaraih dan Alanezi (2011) namun tidak konsisten dengan penelitian Nissim dan Penham (2003) yang menyatakan bahwa stock return tidak mempunyai pengaruh terhadap penilaian ekuitas.

Dividen payout ratio mempunyai nilai significance sebesar 0,623 yang lebih besar dari tingkat signifikansi 0,05 sehingga dapat disimpulkan bahwa dividend payout ratiotidak mempunyai pengaruh terhadap penilaian ekuitas.Nilai dividen sebuah perusahaan tidak akan mempengaruhi nilai ekuitas sebuah perusahaan karena nilai dividen hanyalah sebuah perhitungan yang menjelaskan seberapa besar perusahaan tersebut membagikan dividen tunai kepada pemagang sahamnya. Setiap meningkatnya pembagian dividen yang dibagikan tidak selalu diikuti dengan meningkatnya nilai ekuitas dari perusahaan tersebut, karena nilai ekuitas perusahaan ditentukan oleh laba yang dihasilkan serta kebijakan para pemegang saham dalam melakukan investasi. Hal ini menunjukkan bahwa dividend payout ratiotidak mempunyai pengaruh terahadap penilian ekuitas.

Dividend payout ratio dan penilaian ekuitas memiliki hubungan yang negatif, yaitu besarnya dividen sebuah perusahaan dipengaruhi oleh earning per share, apabila earning per share sebuah perusahaan menurun, maka dividen yang dibagikan akan meningkat sedangkan penurunan earning per share mempengaruhi penurunan nilai ekuitas. Berdasarkan penjelasan di atas menunjukkan bahwa meningkatnya nilai dividend payout ratioakan membuat penurunan penilaian ekuitas. Hasil penelitian ini konsisten dengan penelitian yang dilakukan oleh Popped dan Wang (2005) namun tidak konsisten dengan penelitian Ohlson (2005) yang menyatakan bahwa dividend payout ratio mempunyai pengaruh yang siginifikan terhadap penilaian ekuitas.

\section{PENUTUP}

Simpulan.Pertama, hasil ini penelitian menunjukkan bahwa earning per share tidak mempunyai pengaruh terhadap penilaian ekuitas.Hasil penelitian ini konsisten dengan 
penelitian yang dilakukan oleh Kwon (2009) namun tidak konsisten dengan penelitian Alfariah dan Alanezi, 2011; Nissim dan Penhem, 2003; Pope dan Wang, 2005; Al Hares et al., 2011; Xu et al., 2007; Ohlson, 2005yang menyatakan bahwa earning per sharemempunyai pengaruh terhadap penilaian ekuitas.

Kedua, Price to book value mempunyai pengaruh terhadap penilaian ekuitas. Hasil penelitian ini konsisten dengan penelitian yang dilakukan olehAlfaraih (2011), Gupta (2007), Kwon (2009), dan Osama et al (2011)namun tidak konsisten dengan penelitian Davis dan Gordon (2005) yang menyatakan bahwa price to book value tidak mempunyai pengaruh terhadap penilaian ekuitas.

Ketiga, Cash flow operatingtidak memiliki pengaruh terhadap penilaian ekuitas.Hasil penelitian ini konsisten dengan penelitian yang dilakukan oleh Al Hares et al. (2011) namun tidak konsisten dengan penelitian Kwon (2009) dan Davis and Gordon (2005) yang menyatakan bahwa cash flow operatingmempunyai pengaruh terhadap penilaian ekuitas.

Keempat,Stock return memiliki pengaruh terhadap penilaian ekuitas.Hasil penelitian ini konsisten dengan penelitian yang dilakukan oleh Alfaraih dan Alanezi (2011) namun tidak konsisten dengan penelitian Nissim dan Penham (2003) yang menyatakan bahwa stock return tidak mempunyai pengaruh terhadap penilaian ekuitas.

Kelima, Dividend payout ratiotidak mempunyai pengaruh terhadap penilaian ekuitas.Hasil penelitian ini konsisten dengan penelitian yang dilakukan oleh Popped dan Wang (2005) namun tidak konsisten dengan penelitian Ohlson (2005) yang menyatakan bahwa dividend payout ratio mempunyai pengaruh yang siginifikan terhadap penilaian ekuitas.

Saran. Berdasarkan keterbatasan yang dihadapi dalam pelaksanaan penelitian ini, maka saran yang dapat diberikan adalah pertama, sebaiknya penelitian ini memperluas tahun penelitian agar hasil penelitian lebih mencerminkan kondisi penilaian ekuitas yang lebih baik. Kedua, perlunya penambahan variabel lain yang belum diuji pengaruhnya terhadap penilaian ekuitas dalam penelitian ini seperti, sales, interest rates, retained earning, stock price, dan net income (Nissim, 2003; Gupta, 2007; Xu, 2007; Davis, 2005) sehingga hasil penelitian dapat lebih dikembangkan lagi. Ketiga, alangkah baiknya bila pada penelitian selanjutnya sumber data yang digunakan diperluas lagi tidak hanya berasal dari perusahaan manufaktur namun perusahaan lain yang dapat diteliti penilaian ekuitasnya, agar hasil yang diperoleh lebih jelas menggambarkan tentang penilaian ekuitas dalam perusahaan.

Bagi perusahaan, dapat melakukan penilaian ekuitas tidak hanya berdasarkan laba, return, arus kas, dan juga dividen namun dapat melakukan penilaian ekuitas dengan factor-faktir lain yang juga mempengaruhi ekuitas. Bagi pemegang saham dapat lebih memahami waktu yang tepat dalam menanamkan sahamnya di sebuah perusahaan dan juga lebih memahami seberapa besar return yang akan diperoleh. Bagi peneliti berikutnya, lebih dapat mengembangkan penelitian dengan memperluas data yang akan diuji baik untuk variabel, tahun penelitian, dan juga sektor perusahaan.

\section{DAFTAR RUJUKAN}

Al Hares,Osama M., Naser M. AbughazalehdanAyman E. Haddad. (2011) The Effect of Other Information on Equity Valuation: Kuwait Evidence. The Journal of Applied Business Research.(27). Hal.57-69. 
Alfaraih,Misharidan Faisal Alanezi. (2011) The Usefulness of Earnings and Book Value for equity Valuation to Kuwait Stock Exchange Participans.International Business \& Economics Research Journal.(10). Hal.73-89.

Brighman, Eugene F. dan Joel F. Houston.(2001) ManajemenKeuangan.EdisiKedelepan. Jakarta: PenerbitErlangga. Hal.28, 92, 367.

Darmadji, Tjiptonodan Henry Fakhruddin.(2006) Pasar Modal di Indonesia Pendekatandan Tanya Jawab.EdisiKedua. Jakarta: SalembaEmpat. Hal. 201.

Davis, Paquita Y. dan Elizabeth A. Gordon.(2005) Relative Valuation Roles of Equity Book Value, Net Income, and Cash Flow During A Macroeconomic Shock: The Case of Mexico and The 1994 Currency Crisis. Journal of International Accounting Research.(4). Hal.1-21.

Gee-Jung, Kwon.(2011) The Value Relevance of Book Values, Earnings and Cash Flows: Evidence from Korea.International Journal of Business and Management.(4).Hal.28-42.

Ghozali, Imam. (2011) AplikasiAnalisis Multivariate Dengan Program IBM SPSS 20.EdisiEnam.Semarang: BadanPenerbitUniversitasDiponegoro.

Gupta, Dr. Ramesh. (2007) Accounting Based Valuation Models and Security Prices in India-An Empirical Assessment.The Business Review.(7). Hal.158-163.

IkatanAkuntansi Indonesia. (2002) StandarAkuntansiKeuanganPer 1 April 2002. Jakarta: SalembaEmpat.

Jogiyanto.(2003) TeoriPortofoliodanAnalisisInvestasi.EdisiKetiga. Yogyakarta: BPFEYogyakarta. Hal.110-111.

Kieso, Weygandtdan Warfield. (2011) Intermediate Accounting. Volume $2^{\text {nd }}$.United Stated of America: John Wiley \& Sons.Hal.772, 1242.

Nissim,Dorrondan Stephen H. Penham. (2003) The Association Between Changes in Interest Rates, Earnings, and Equity Values.Contemporary Accounting Research.(20).Hal.775-804.

Ohlson, James A. (2005) Earnings, Book Value, and Dividend in Equity Valuation.Contemporary Accounting Research.(11).Hal.661-687.

Pope, Peter F. danPengguo Wang. 2005. Earnings Components, Accounting Bias and Equity Valuation.Review of Accounting Studies.(10). Hal.387-407.

Priyatno, Duwi. (2010) PahamAnalisaStatistik Data dengan SPSS.EdisiPertama. Yogyakarta: Media Kom.

Rayhorn, Charles dan Kenneth Jansen. (2014) Price to Earnings and Market to Book Matrics in The Practical Application of Discounted Dividend Theory of Equity Valuation.Journal of Business and Behavioral Sciences.(26).Hal.168-175.

Suwardjono.(2011)Teori Akuntansi Perekayasaan Pelaporan Keuangan. Edisi Ketiga. Yogyakarta: BPFE-Yogyakarta. Hal.184, 583.

Warren, Reeve, dan Fess. (2005) Accounting: international student edition. Twentieth One Edition. South Western: Thomson Corporation. Hal. 658.

Wolk, Harry I. dan Michael G. Tearney. (1997) Accounting: A Conceptual and Institutional Approach. Fourth Edition. Ohio: International Thomson Publishing. Hal.91. 